HSE Economic Journal, 2019, vol. 23, no 1, pp. 314-330.

\title{
Value Relevance of Government Ownership of Equity (Evidence from Russian Listed Companies)
}

\author{
Anastasia Maga ${ }^{1}$, Elizaveta Baranova ${ }^{2}$, \\ Zhargal Tumunbayarova ${ }^{3}$ \\ ${ }^{1}$ Stamford International University, \\ Rama 9 Campus 16, Motorway Road - Km, Prawet, Bangkok, 10250, Thailand. \\ E-mail: anastasia.maga@stamford.edu \\ 2 Trans-Baikal State University, \\ 30, Alexandro-Zavodskaya, Chita, 672039, Russian Federation. \\ E-mail: baranova_chita@mail.ru \\ 3 Trans-Baikal State University, \\ 30, Alexandro-Zavodskaya, Chita, 672039, Russian Federation. \\ E-mail: tzhargal@list.ru
}

The impact of government ownership of a firm's equity has generated much discussion in finance, economics, and politics. Extant literature provides evidence of both positive and negative effect of government ownership on the market value of firms with multiple reasons in favor of both effects. There has also been research on how such effects may differ in different markets. This paper aims to explore value-relevance in Russian financial markets. We are exploring the relationship between government ownership of a firm's equity on its market value in Russia with the view of answering the research question of how investors in Russia perceive the fact and degree of government ownership on equity measured through the market value of equity. We are using a sample of 159 Russian listed companies to identify relationships between market value and government ownership of equity. Previous studies support a positive relationship between such variables, however evidence from Russian listed firms proves otherwise. We find little statistically significant evidence of such association in the market in general, however the industry effect proved to be significant; we find that government control is severely penalized in manufacturing, while rewarded in service sectors; this effect also depends on the concentration of government ownership. This research connects to the efficient market hypothesis (EMH).

Anastasia Maga - Thailand Lecturer, Faculty of Business and Technology.

Elizaveta Baranova - Associate Professor, Faculty of Economics and Management.

Zhargal Tumunbayarova - Associate Professor, Faculty of Economics and Management.

The article was received: 14.01.2019/The article is accepted for publication: 03.04.2019. 
Key words: government ownership; market value; value relevance.

JEL Classification: G18, G32, 052.

DOI: $10.17323 / 1813-8691-2019-23-2-314-330$

\section{Introduction}

The structure of ownership of firm equity has been widely discussed as contributing to both positive and negative influences on various aspects of performance. Two main streams of literature exist in this relation, the most prominent one being the one exploring various effects government ownership of a firm's equity exerts on its financial performance, and the less significant in volume being the stream on the direct market value relevance of government control. Both literatures have in common the view that governmental ownership can have both positive and negative effects on either one of the performance indicators. Our research contributes to the latter and dwells upon the efficient market hypothesis (EMH) [Fama, 1998] supporting current market value of the firm's equity contains the publicly available data on the equity structure as well as other information, meaning that investors making decisions to purchase a particular share of stock will consider this information, thus knowing about the fact and degree of state-control over a firm and expressing their attitude towards it.

We are exploring the relationship between government ownership of a firm's equity on its market value in Russia with the view of answering the research question of how investors in Russia perceive the fact and degree of government ownership on equity measured through the market value of equity. Carney and Child (2013) report a growing role of government in equity ownership in East Asian countries between 1996 and 2008. Boubakri, Ghoul, Guedhami and Meggisnson (2017) report that in emerging markets SOEs (State owned enterprises) account for $28 \%$ of the largest companies. However, despite active privatization in both developed (mostly Europe) and developing markets (Asian countries, East Europe, Latin America) the share of state-controlled companies continues to grow, but a more active phase of this growth occurred after the financial crisis, when government ownership started to be associated with a bailout strategy and certain references in receiving support [Guedhami, 2012; Nash, 2017].

Further observation with regard to government ownership of firms' equity, found some companies were formed due to privatization of SOE's capital and the government retained a proportion of equity (usually around $50 \%$ as reported by Tran, Nonneman \& Jorrisen (2014)). In other cases, ownership was obtained by purchasing a share of equity in the market, the result being seen in the form of low percentage of government ownership of the firm's equity. Such acquisition was reported by Eckel and Vermaelen (1986) for North American firms. Thus, the trend reported by the extant research shows the proliferation of the latter form of acquisition after the financial crisis in Europe and Asia, presumedly in response to the crisis effects, with some evidence in favor of a more positive perception of such a type by investors, but again the findings differ depending on economy [Huang, Xiao, 2012] and firm size [Truong et al., 2006].

Our research explores the relationship between government ownership and market value for Russian listed firms. We are using evidence from a sample of 159 publicly traded firms listed in the stock exchange of Russia found in Bloomberg database, the study is cross-sectional and relies on data obtained for the year 2017. 


\section{Literature review}

The extant literature abounds in research on value relevance of various corporate engagements, including financial and non-financial information with the main theoretical concept being the efficient market hypothesis (EMH) [Fama, 1970; 1998; Kendall, 1958] stating that share prices contain all publicly available information, including information on the public ownership of the firm's equity.

The literary background of market value research started in 1953, when Maurice Kendall published his seminal paper elaborating on the «random walk» proposition [Kendall, 1953] having proved that stock prices fluctuate independently of one another, that they have the same probability distribution, hence probability theory can be applied, and that stock and commodity prices in the long term tend to maintain an upward trend. The stock price movements in Kendall's model are martingales. The same concept was later formalized by Samuelson (1965) in his seminal paper «Proof that properly anticipated prices fluctuate randomly» and the Random Walk Hypothesis (RWH) thus took its shape, and later came to be known as weak-form efficiency.

Subsequently the concept was developed by Gene Fama with his Efficient Market Hypothesis (EMH), which stipulates that stock prices contain all relevant information, but there are three different forms of efficiency under the hypothesis [Fama, 1970; 1991]:

- The weak form, under which the current prices reflect all information contained in the record of past prices.

- The semi-strong form suggests that current prices contain not only historical prices but also all other publicly available information. into stocks.

- The strong form states that all information, both public and private, is instantly priced

The evidence in support of the EMH has been substantial over the years, mainly relying on the failure of fund managers to outperform the market [Fenton O'Creevy et al., 2005; Fama, 1991].

Various effects on market value were being explored at that same time, for instance the Modigliani-Miller hypothesis (M\&M) stated that, under the conditions of a perfect market, in the absence of taxes, the total market value of a firm is not affected by its capital structure [Modigliani, Miller, 1958]. In the light of the M\&M paradox a question logically arose as to what affects the market value and how firms capitalize on it. The help came from Jensen and Meckling's Agency Cost theory (1976). The agency approach stated that the capital structure matters as debt is a good disciplinarian for managers, and the ownership structure matters as well because managerial behavior is affected by their own interest, that assumption will work in case of managerial ownership. Under more realistic conditions, however, with inclusion of taxes and bankruptcy costs, the M\&M paradox did not hold [Modigliani, Miller, 1963; Morck, Shleifer, Vishny, 1988] and two streams of literature developed in relation to the effect of ownership structure on firm value: management ownership and concentration of ownership, both discuss the ways to reduce agency costs.

The managerial ownership, also referred to as insider ownership, dwells on the convergence of interest hypothesis to explain the positive impact of managerial ownership on market value [Morck, Shleifer, Vishny, 1988]. However, results of studies attempting to find the link between insider ownership and market value have been mixed. 
The concentration of ownership effect is based on the efficient monitoring hypothesis [Pound, 1988], stating that firms with more concentrated ownership structures have better financial and market performance, because of more efficient management input coming from the single investor, shareholders' activism has less embedded conflicts, the efforts of managers are better coordinated with those of the shareholder, hence agency cost is reduced.

Another view at ownership structure is government ownership of a firm's equity, However, research on the impact of government ownership on market value lacks an extensive history. The object of such a consideration is a mixed enterprise, defined by Spenser (1959) as joint ownership by public and private management. Such ownership is described as the result of either state-owned enterprise (SOEs) being privatized but government retaining its stake, or state acquisition of shares of a private jointly owned enterprise.

The first intensive research into the effect of state ownership on the market value of a firm was made by Eckel and Vermaelen (1986), who reported both negative and positive impact, the positive including expectation of lower risk and access to subsidy, synergistic effects; the negative ones being lower expected profitability capitalizing into share prices. The authors connected research to a conceptual framework of agency approach under the perception of alignment of agents' interests with principal ones, but dependent upon the degree of regulation.

Since then there has been two parallel streams of literature exploring the effects of public ownership: market value relevance effects and the financial performance effects, the results of both streams can be linked by the overarching concept of EMH and agency approach under it, dwelling on possible agency costs from misalignment of owner's interests with the agent's ones, and possible agency gains from the same misalignment.

It has to be noted that significantly less studies found purely positive effects (agency gains) of state involvement [Jiang et al., 2008; Liao, Young, 2012], and more studies identified various either negative [Sappington, Stiglitz, 1987; Shleifer, Vishny, 1994; Boycko et al., 1996] or mixed [Wei et al., 2005; Hess et al., 2010; Alfaraih, Alanezi, Almujamed, 2012] effects. The main reasons for negative effects listed as agency conflict, and positive impact attributed to lower risk perception. It has also been found that transition economies may show different effects [Huang, Xiao, 2012]. The most interesting explanation provided by the current literatures is the one contrasting the «helping hand» with the «grabbing hand» of the government, which might take advantage of its controlling position and abuse the earnings [Sappington, Stiglitz, 1987]. Thus, the main assumption in exploring the value relevance of government ownership is the cost effect.

We will connect to the stream of literature of purely market effects of governmental ownership, examining the latter as an independent variable in market valuation [Alfaraih, Alanezi, Almujamed, 2012; Razak, Saidi, Mahat, 2013] in the widely used valuation model by Ohlson (1995), which serves to measure certain value effects [Ohlson, 1995; Hassel, 2005; Loh et al., 2017]. We will also connect to literature on the concentration of ownership effect.

Our goal is to explore the effect of government ownership of firm equity in Russia. In doing so, we have developed three hypotheses.

Hypothesis 1 (H1): Firms with any degree of government ownership (>0) have lower total market values than purely privately owned firms.

H1 explores the market value relevance in association with government control, connecting to the EMH and previous research supporting the expectation of agency conflict [Eckel, Vermaelen, 1986] and the «grabbing hand» effect by the investor [Huang, Xiao, 2012]. 
Hypothesis 2 (H2): Firms with higher concentration of government ownership have lower market value values than firms with lesser degree of government control.

H2 connects to the concept of ultimate control [Wang, Xiao, 2009] where the degree of government control is ranging between 0 and $100 \%$ assuming that less state control translates into better performance of firms in terms of profitability and productivity [Tran et al., 2014].

Hypothesis 3a (H3a): Firms with higher concentration of government ownership (over $25 \%$ ) have higher market values than firms with the concentration of government ownership less than $25 \%$.

Hypothesis $\mathbf{3 b}(\mathrm{H} 3 \mathrm{~b})$ : Firms with higher concentration of government ownership (over $50 \%$ ) have higher market values than firms with the concentration of government ownership less than $50 \%$.

H3 tests the concentration of ownership effect to see if it will overpower the effect of ultimate control, with the cutoff values of $25 \%$ and $50 \%$ of the equity ownership [Husain, Hazoor, Sabir, 2014].

\section{Data and Methods}

The empirical analysis relies on a sample of 159 firms out of the target population of 260 corporations listed in the Russian financial market. We used data derived from the Bloomberg database including those on government ownership, market value, and other variables. Data analysis is done with the help of statistical software IBM SPSS and R.

In this study, we are using a derivative of Ohlson's (1995) model of a firm's market value relation to accounting data and other information. In finance and accounting research Ohlson's valuation model is viewed as a conventional tool in determining value-relevance of various data [Hassel, 2005; Loh et al., 2017; Lourenco, Eugenio, 2011].

The model is using a regression tool to determine the nature of the relationship between variables and the impact of independent variables on the intercept. As long as the data on market value is heterogeneous, we are using the weighted least squares regression method. Our model derivation is based on the method used by Loh and Thomas (2017) with modifications in terms of ownership variable. We will test several specifications of the model with the baseline having the following shape:

$$
M V_{i, t+4}=\alpha 0+\alpha l B V_{i, t}+\alpha 2 E A R N_{i, t}+\alpha 3 E A R N_{i, t} \cdot N E G_{i, t}+\varepsilon_{i, t} .
$$

In the model $M V_{i, t+4}$ is the market value four months after the financial year-end of company $i$; $B V_{i, t}$ is the book value of common equity at the year-end of company $i$; $E A R N_{i, t}$ is earnings before extraordinary items at the year-end of company $i ; N E G_{i, t}$ is a dummy variable equal to 1 if at the $t$ year end the firm had losses and 0 if otherwise, and $\varepsilon i, t$ is the error term. We are including book value and earnings, because in previous research [Loh et al., 2017; Hassel, 2005; Ohlson, 1995] book value shows a positive relationship with market value, earnings, in contrast, it can show a negative relationship with market value, because profit is usually rewarded by the market and loss is usually penalized [Brecht et al., 2018]. First we run it as Model (1) and test its specifications. 
As the next step we will include the ownership variable first as a dummy variable, with 0 if the firm had no state ownership and 1 - if there was some degree of it (dummy variable $O W N_{i, t}$ ), to find the link between the ownership and the market value to accept/reject the hypothesis H1 (Model 2). To test the hypothesis 2 (H2) we explore the relationship between the degree of government ownership and market value replacing the dummy variable $O W N_{i, t}$ with a continuous variable, the share of equity owned by the government (between 0 and 100\%) and produce model (3). After that we will generate the model (4), containing a control variable; for the control variable we chose to use the firms belonging to service or manufacturing sector, the $I N D_{i, t}$ variable, which we assign the value - «0» if its service and « 1 » if the company works in the manufacturing sector.

Assessing the model specification and predicting power we will examine the $R^{2}$ for the three models and the p-values for the significance of the relationships, we are expecting to see a value of determination coefficient of more than 0,5 , which would mean that the model can predict $50 \%$ of the variance of market value by the change in book value, earnings and profit/loss (model 1), we expect the value of $R^{2}$ to remain relatively constant for subsequent model specifications, at the significance level of $p$ below 0,05 . Therefore if the association proves to be statistically significant ( $p$-value below 0,05 ) we will accept that the association did not happen by chance; if otherwise we will accept the null hypothesis (no significant relationship).

\section{Findings}

1019 firms in total are listed in Russian financial markets, however out of those firms only 260 are active and report financials. And only 159 of the active 260 firms have enough values reported for analysis. The selected 159 firms are characterized by high market values, have varied earnings and mostly larger book values of equity. The distribution of firms by main variables is positively skewed with a number of large outliers.

Table 1 summarizes the summary statistics of all variables used in this research describing the central tendency and the dispersion of variables used in the model.

Table 1.

Summary statistics of variables

\begin{tabular}{l|l|r|r|r|r}
\hline & N & \multicolumn{1}{c}{ Minimum } & Maximum & \multicolumn{1}{c}{ Mean } & \multicolumn{1}{c}{ Std. Deviation } \\
\hline MV, mln RUB & 159 & $-4964,4$ & 2823929,3 & 570390,1 & 2618195,2 \\
EARN, mln RUB & 159 & -405551 & 1022376 & 31185,9 & 133187,1 \\
OWN & 159 & 0 & 99,997 & 19,65 & 35,199 \\
BV, mln RUB & 159 & -284833 & 12015481,4 & 248861,8 & 1123554,4 \\
\hline \hline
\end{tabular}

Absolute values are shown in RUB, the mean value of earnings before extraordinary items for the sample was 31185,9 million RUB and the mean book value was almost 25 billion RUB, the mean market value for Russian listed companies was 570 trillion RUB. Government 
ownership in the sample ranged between $0 \%$ and almost $100 \%$ with the mean value of $19,65 \%$, which is quite high. However only 58 firms out of the 159 (36,5\%) had some degree of government control with the mean value of $53,9 \%$. The distribution is bimodally shaped with more than $70 \%$ of the firms having the degree of government control between 0 and $10 \%$.

Correlation matrix of the variables

Table 2.

\begin{tabular}{l|l|l|l|l|l|l|l}
\hline & IND & MV & EARNNEG & EARN & BV & OWN\% & OWNd \\
\hline IND & 1 & $-0,098$ & 0,114 & 0,111 & 0,099 & $0,175^{*}$ & $0,178^{*}$ \\
MV & & 1 & $-0,017$ & $0,680^{* *}$ & $0,505^{* *}$ & $0,244^{* *}$ & $0,217^{* *}$ \\
EARNNEG & & & 1 & $0,272^{* *}$ & 00,042 & 0,048 & 0,067 \\
EARN & & & 1 & $0,902^{* *}$ & $0,279^{* *}$ & $0,306^{* *}$ \\
BV & & & & 1 & $0,262^{* *}$ & $0,264^{* *}$ \\
OWN\% & & & & & 1 & $0,739^{* *}$ \\
OWNdum & & & & & $0,739^{* *}$ & 1 \\
\hline \hline
\end{tabular}

${ }^{*}$ Correlation is significant at the 0,05 level (2-tailed).

${ }^{* *}$ Correlation is significant at the 0,01 level (2-tailed).

From the correlation matrix (Pearson correlations) we can see a high value of correlation coefficient between earnings and book value 0,9 at a high significance level), we explain that by the simple pattern that firms having high book value of equity will be larger and have higher value of sales, such correlation is common for all markets, we will control the model for multicollinearity with variance inflation factors (VIFs). Among other peculiarities we can point out high significance of association between market value and the main independent variables of the model, however our model is using the weighted method so we cannot rely on the significances shown by Pearson values.

Table 3.

Model 1 Regression Results

\begin{tabular}{l|c|c|c|c|c|c|c}
\hline & \multicolumn{2}{|c|}{$\begin{array}{c}\text { Unstandardized } \\
\text { coefficients }\end{array}$} & \multicolumn{3}{c|}{$\begin{array}{c}\text { Standardized } \\
\text { coefficients }\end{array}$} & \multicolumn{2}{c}{$\begin{array}{c}\text { Collinearity } \\
\text { statistics }\end{array}$} \\
\cline { 2 - 8 } & $\mathrm{B}$ & Std. error & Beta & $\mathrm{t}$ & Sig. & Tolerance & VIF \\
\hline BV & 0,751 & 0,438 & 0,184 & 1,712 & 0,049 & 0,389 & 2,570 \\
EARN & 18,407 & 5,287 & 0,726 & 3,481 & 0,001 & 0,103 & 9,703 \\
EARNNEG & $-23,544$ & 5,546 & $-0,792$ & $-4,245$ & 0,000 & 0,129 & 7,759 \\
$\mathrm{R}^{2}$ & 0,305 & & & & & & \\
\hline
\end{tabular}

The first regression showed that the selected model functioned in predicting the variance of the intercept, the market value, with the $R^{2}$ higher than 0,3 and all independent variables showing statistically significant relationships with the market value (p-values are less than 0,05 ). 
We conclude that our model has a good fit, but there are unobserved factors influencing the intercept. Thus, we need to test other models.

Table 4.

Model 2 Regression Results

\begin{tabular}{|c|c|c|c|c|c|c|c|}
\hline & \multicolumn{2}{|c|}{$\begin{array}{l}\text { Unstandardized } \\
\text { coefficients }\end{array}$} & \multicolumn{3}{|c|}{$\begin{array}{l}\text { Standardized } \\
\text { coefficients }\end{array}$} & \multicolumn{2}{|c|}{$\begin{array}{l}\text { Collinearity } \\
\text { statistics }\end{array}$} \\
\hline & B & Std. error & Beta & $\mathrm{t}$ & $\mathrm{p}$-value & $\mathrm{t}$ & VIF \\
\hline BV & 0,793 & 0,443 & 0,194 & 1,788 & 0,046 & 0,382 & 2,619 \\
\hline EARN & 18,569 & 5,301 & 0,733 & 3,503 & 0,001 & 0,103 & 9,722 \\
\hline EARNNEG & $-23,734$ & 5,562 & $-0,798$ & $-4,267$ & 0,000 & 0,129 & 7,778 \\
\hline OWNdum & $-112952191148,399$ & 162021923420,974 & $-0,049$ & $-0,697$ & 0,487 & 0,928 & 1,077 \\
\hline Adjusted $\mathrm{R}^{2}$ & 0,307 & & & & & & \\
\hline
\end{tabular}

Having included the factor of ownership (as a dummy variable) into the model we find that government ownership of the firm's equity may have a slightly negative impact on the market value, however we need to reject such an association because the level of significance (p-value of 0,487 ) doesn't allow us to admit that such an association did not happen by chance. Thus, we accept the null hypothesis. So, H1 does not hold for our sample.

Table 5.

Model 3 Regression Results

\begin{tabular}{|c|c|c|c|c|c|c|c|}
\hline & \multicolumn{2}{|c|}{$\begin{array}{l}\text { Unstandardized } \\
\text { coefficients }\end{array}$} & \multicolumn{3}{|c|}{$\begin{array}{l}\text { Standardized } \\
\text { coefficients }\end{array}$} & \multicolumn{2}{|c|}{$\begin{array}{l}\text { Collinearity } \\
\text { statistics }\end{array}$} \\
\hline & B & Std. error & Beta & $\mathrm{t}$ & p-value & $\mathrm{t}$ & VIF \\
\hline BV & 0,810 & 0,444 & 0,198 & 1,823 & 0,050 & 0,380 & 2,634 \\
\hline EARN & 18,533 & 5,294 & 0,731 & 3,501 & 0,001 & 0,103 & 9,710 \\
\hline EARNNEG & $-23,706$ & 5,554 & $-0,797$ & $-4,268$ & 0,000 & 0,129 & 7,768 \\
\hline OWN\% & $-2044356010,266$ & 2384419998,191 & $-0,060$ & $-0,857$ & 0,393 & 0,923 & 1,083 \\
\hline Adjusted $\mathrm{R}^{2}$ & 0,308 & & & & & & \\
\hline
\end{tabular}

Having replaced the dummy variable - government ownership - with a continuous one, we again do not find any statistically significant relationship between the degree of ownership and the firm's value (the p-value 0,393), we can still see a high impact of book value and earnings on market value, but still government ownership does not produce any significant effect. However the significance of this association has increased with the change of variable from $p$-value of 0,487 to 0,393 , we cannot accept or reject the hypothesis 2 (H2) under these conditions also.

Testing the Hypotheses $3 \mathrm{a}$ and $3 \mathrm{~b}$, examining the concentration of ownership effect we will transform the continuous variable $\mathrm{OWN}$ into a dummy variable based on the cutoff values of 25\% (Model 4) and 50\% (Model 5). 
Models 4 and 5 Regression Results

Table 6 .

\begin{tabular}{|c|c|c|c|c|c|c|c|c|}
\hline & Model 4 & Model 5 & & Model 4 & & & Model 5 & \\
\hline & \multirow{2}{*}{\multicolumn{2}{|c|}{$\begin{array}{l}\text { Unstandardized } \\
\text { coefficients (B) }\end{array}$}} & \multicolumn{3}{|c|}{$\begin{array}{c}\text { Standardized } \\
\text { coefficients }\end{array}$} & \multicolumn{3}{|c|}{$\begin{array}{c}\text { Standardized } \\
\text { coefficients }\end{array}$} \\
\hline & & & Beta & $\mathrm{t}$ & $\mathrm{p}$-value & Beta & $\mathrm{t}$ & p-value \\
\hline Constant & 11838170010,262 & 11153490704,116 & & 0,654 & 0,514 & & 0,616 & 0,539 \\
\hline BV & 18,541 & 18,465 & 0,732 & 3,503 & 0,001 & 0,729 & 3,494 & 0,001 \\
\hline EARN & $-23,715$ & $-23,651$ & $-0,798$ & $-4,270$ & 0,000 & $-0,796$ & $-4,266$ & 0,000 \\
\hline EARNNEG & 0,817 & 0,841 & 0,200 & 1,835 & 0,068 & 0,206 & 1,885 & 0,061 \\
\hline OWN25 & $-171109766930,26$ & & $-0,062$ & $-0,882$ & 0,379 & & & \\
\hline OWN50 & & $-216951680617,85$ & & & & $-0,076$ & $-1,079$ & 0,282 \\
\hline Adjusted $\mathrm{R}^{2}$ & 0,290 & 0,292 & & & & & & \\
\hline
\end{tabular}

Results on Models 4 and 5 demonstrate lack of evidence to the concentration of ownership effect in case of government ownership in the Russian financial market. Not only may the associations have happened by chance (due to high p-values), but also the model fit is significantly reduced if we to use concentration as a factor. Thus, in case of $\mathrm{H} 3 \mathrm{a}$ and $\mathrm{H} 3 \mathrm{~b}$ we retain the null hypothesis.

As the next step we want to test the model specification, we note a large impact of unobservable factors which we attempt to identify, thus we will try to test at least one control variable.

Observing the data we find a patent in government ownership by industry sector (Table 7). The highest concentration of government ownership we find in the oil, energy and web-design sectors; the smallest concentration exists in software development.

Table 7.

Cross-tabulation of Industry and Owner

\begin{tabular}{lr|r|r|r}
\hline \multicolumn{1}{c|}{ GICS Sector } & Government & Ownership & Total & Ownership, \% \\
\hline Oil & 8 & 7 & 15 & 46,67 \\
Mining \& Metals & 20 & 9 & 29 & 31,03 \\
Transport & 13 & 6 & 19 & 31,58 \\
Automobile & 11 & 1 & 12 & 8,33 \\
Retail & 9 & 2 & 11 & 18,18 \\
Software & 4 & 0 & 4 & 0,00 \\
Banking & 11 & 3 & 14 & 21,43 \\
Web & 1 & 3 & 4 & 75,00 \\
Telecom & 4 & 2 & 6 & 33,33 \\
Energy & 14 & 24 & 38 & 63,16 \\
Investment & 6 & 1 & 7 & 14,29 \\
Total & 101 & 58 & 159 & \\
\hline \hline
\end{tabular}




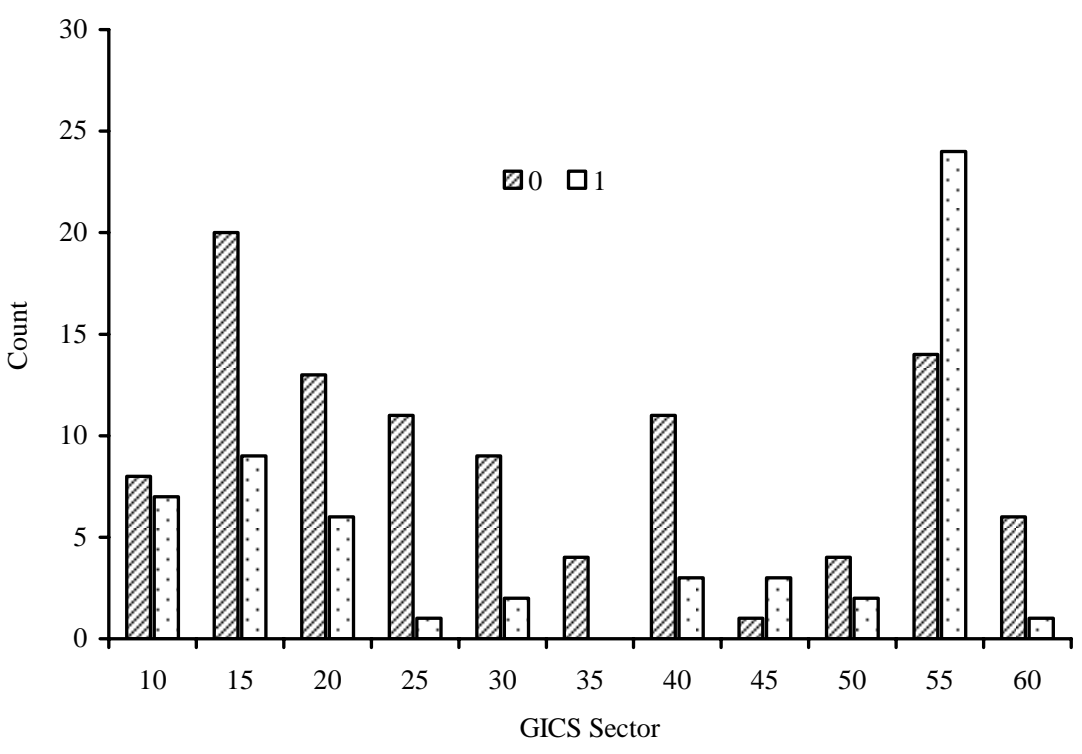

Fig. 1. Distribution of ownership by sector ${ }^{1}$

To check how the sector can affect the market value we will include the variable into the model as a dummy, with «0» assigned to the service sectors and «1» - to manufacturing.

Table 8.

Correlation matrix including the industry factor

\begin{tabular}{|c|c|c|c|c|c|c|c|}
\hline & IND & MV & EARNNEG & EARN & BV & OWN\% & OWNdum \\
\hline IND & 1 & $-0,098$ & 0,114 & 0,111 & 0,099 & $0,175^{*}$ & $0,178^{*}$ \\
\hline MV & & 1 & $-0,017$ & $0,680^{* *}$ & $0,505^{* *}$ & $0,244^{* *}$ & $0,217^{* *}$ \\
\hline EARNNEG & & & 1 & $0,272^{* *}$ & 0,042 & 0,048 & 0,067 \\
\hline EARN & & & & 1 & $0,902^{* *}$ & $0,279^{* *}$ & $0,306^{* *}$ \\
\hline BV & & & & & 1 & $0,262^{* *}$ & $0,264^{* *}$ \\
\hline OWN\% & & & & & & 1 & $0,739^{* *}$ \\
\hline OWNdum & & & & & & $0,739^{* *}$ & 1 \\
\hline
\end{tabular}

${ }^{*}$ Correlation is significant at the 0,05 level (2-tailed).

** Correlation is significant at the 0,01 level (2-tailed).

Regression of both models with the industry variable (Model 6 and Model 7) shows a significant increase in the determination coefficient value, which means a better fit of the model,

\footnotetext{
1 GICS classification.
} 
also the p-values of the variables have significantly improved, however the VIF for the variable $E A R N$ reached critical proportions, which means there is more collinearity between market value and earnings depending on the industry.

Table 9.

Model 6 Regression Results

\begin{tabular}{|c|c|c|c|c|c|c|c|}
\hline & \multicolumn{2}{|c|}{$\begin{array}{l}\text { Unstandardized } \\
\text { coefficients }\end{array}$} & \multicolumn{3}{|c|}{$\begin{array}{l}\text { Standardized } \\
\text { coefficients }\end{array}$} & \multicolumn{2}{|c|}{$\begin{array}{l}\text { Collinearity } \\
\text { statistics }\end{array}$} \\
\hline & B & Std. error & Beta & $\mathrm{t}$ & p-value & $\mathrm{t}$ & VIF \\
\hline BV & 1,307 & 0,474 & 0,320 & 2,756 & 0,007 & 0,320 & 3,120 \\
\hline EARN & 11,858 & 5,757 & 0,468 & 2,060 & 0,041 & 0,084 & 11,938 \\
\hline EARNNEG & $-16,599$ & 6,056 & $-0,558$ & $-2,741$ & 0,007 & 0,104 & 9,598 \\
\hline OWNdum & $-128641297806,8$ & 158903061213,5 & $-0,055$ &,- 810 & 0,419 & 0,927 & 1,079 \\
\hline IND & $-91441972514,0$ & 33802223268,7 & $-0,199$ & $-2,705$ & 0,008 & 0,797 & 1,254 \\
\hline Adjusted $\mathrm{R}^{2}$ & 0,339 & & & & & & \\
\hline
\end{tabular}

Model 7 Regression Results

Table 10.

\begin{tabular}{|c|c|c|c|c|c|c|c|}
\hline & \multicolumn{2}{|c|}{$\begin{array}{l}\text { Unstandardized } \\
\text { coefficients }\end{array}$} & \multicolumn{3}{|c|}{$\begin{array}{l}\text { Standardized } \\
\text { coefficients }\end{array}$} & \multicolumn{2}{|c|}{$\begin{array}{l}\text { Collinearity } \\
\text { statistics }\end{array}$} \\
\hline & B & Std. error & Beta & $\mathrm{t}$ & $\mathrm{p}$-value & $\mathrm{t}$ & VIF \\
\hline BV & 1,325 & 0,475 & 0,324 & 2,789 & 0,006 & 0,319 & 3,136 \\
\hline EARN & 11,806 & 5,751 & 0,466 & 2,053 & 0,042 & 0,084 & 11,932 \\
\hline EARNNEG & $-16,555$ & 6,049 & $-0,557$ & $-2,737$ & 0,007 & 0,104 & 9,593 \\
\hline IND & $-91523929612,8$ & 33768164183,866 & $-0,199$ & $-2,710$ & 0,007 & 0,797 & 1,254 \\
\hline OWN\% & $-2254663460,9$ & 2338047178,740 & $-0,066$ & $-0,964$ & 0,336 & 0,922 & 1,084 \\
\hline Adjusted $\mathrm{R}^{2}$ & 0,340 & & & & & & \\
\hline
\end{tabular}

Therefore, including the control variable proved to be efficient for the model fit; the predicting power increased to 0,34 , we conclude that belonging to the service sector has a significant effect on the market value. We find that the IND variable, initially intended as a control variable, improves the overall fit of the model, however the significance values, even though improved, still haven't reached the level of significance, we cannot reject the null hypothesis regarding the government ownership.

However, our evaluation of Hypotheses $3 \mathrm{a}$ and $3 \mathrm{~b}$ changes as we add the IND variable. As we add the industry factor the cutoff value of $25 \%$ ownership still has no significant relationship with the market value, but the cutoff value of $50 \%$ gains significance at the p-level of 
0,021 with the beta-value of 0,173 , which is evidence of positive effect of highly concentrated government ownership (> 50\%) on firm market value (Table 11).

Table 11.

Models 8 and 9 Regression Results

\begin{tabular}{|c|c|c|c|c|c|c|c|c|}
\hline & Model 8 & Model 9 & & & & & Model 9 & \\
\hline & \multirow{2}{*}{\multicolumn{2}{|c|}{$\begin{array}{l}\text { Unstandardized } \\
\text { coefficients (B) }\end{array}$}} & \multicolumn{3}{|c|}{$\begin{array}{l}\text { Standardized } \\
\text { coefficients }\end{array}$} & \multicolumn{3}{|c|}{$\begin{array}{l}\text { Standardized } \\
\text { coefficients }\end{array}$} \\
\hline & & & Beta & $\mathrm{t}$ & $\mathrm{p}$-value & Beta & $\mathrm{t}$ & $\mathrm{p}$-value \\
\hline BV & $-2,428$ & $-2,442$ & $-1,033$ & $-5,541$ & 0,000 & $-1,039$ & $-5,662$ & 0,000 \\
\hline EARN & 34,447 & 34,440 & 1,648 & 8,868 & 0,000 & 1,647 & 9,010 & 0,000 \\
\hline EARNNEG & 0,817 & 0,841 & 0,150 & 1,635 & ,038 & 0,206 & 1,885 & 0,041 \\
\hline IND & $-2228053195287,760$ & $-2435895202642,270$ & $-0,242$ & $-3,330$ & 0,002 & $-0,264$ & $-3,631$ & 0,001 \\
\hline OWN25 & 1256492764411,440 & & 0,141 & 1,945 & 0,057 & & & \\
\hline OWN50 & & 1471106295392,430 & & & & 0,173 & 2,376 & 0,021 \\
\hline Adjusted $\mathrm{R}^{2}$ & 0,31 & 0,34 & & & & & & \\
\hline
\end{tabular}

\section{Discussion}

In the course of our analysis we had to reject any impact of government ownership on firm value, neither the fact nor the degree of government ownership affect the market value of a firm in any way. The relationship may seem negative, possibly indicting that state control is penalized by the market, but such an association hasn't been proved by this research.

However, as long as we discovered significant impact from the industrial factor we need to explore that question in further detail. For this, samples should be divided into industry-based groups and evaluation made on the impact of government ownership in the groups with sufficient number of cases to do a regression analysis (more than 25, more than 5 observations per variable).

The sectors identified as suitable for such an analysis are: mining and metals, transportation and banking.

Mining. Variance of the market value in the mining sector can be predicted with a high certainty (determination coefficient of 0,94 and p-values below 0,05 ) with earnings, book value and the degree of government ownership. The sector sample is fairly homogenous and normally distributed, and no significant collinearity was detected, so we used a minimal least squares method (Table 12).

Government ownership is significant and had a strong negative impact on market value (beta-value of $-0,413$ ). The result means that the market largely penalizes government ownership in mining and metals sector, which we explain by the expectation of the "grabbing hand» effect, with government abusing the rents generated by the sector.

Banking. Using the same model specification we can predict up to $99 \%$ of variance in market value in the banking sector (Table 13). 
Regression Results for mining and metals

Table 12.

\begin{tabular}{|c|c|c|c|c|c|}
\hline & \multicolumn{2}{|c|}{ Unstandardized coefficients } & \multicolumn{3}{|c|}{ Standardized coefficients } \\
\hline & B & Std. error & Beta & $\mathrm{t}$ & p-value \\
\hline EARN & 16,485 & 0,975 & 1,404 & 16,913 & 0,000 \\
\hline BV & $-1,127$ & 0,206 & $-0,363$ & $-5,461$ & 0,000 \\
\hline OWN\% & $-6502049224,706$ & 1406264686,241 & $-0,413$ & $-4,624$ & 0,000 \\
\hline EARNNEG & 15,846 & 35,909 & 1,347 & 0,441 & 0,663 \\
\hline Adjusted $\mathrm{R}^{2}$ & 0,939 & & & & \\
\hline
\end{tabular}

Regression Results for Banking

\begin{tabular}{l|rr|r|r|r}
\hline & \multicolumn{2}{|c|}{ Unstandardized coefficients } & \multicolumn{3}{c}{ Standardized coefficients } \\
\cline { 2 - 6 } & $\mathrm{B}$ & \multicolumn{1}{c}{ Std. error } & Beta & $\mathrm{t}$ & $\mathrm{p}$-value \\
\hline EARN & $-6,213$ & 0,863 & $-0,200$ & $-7,201$ & 0,000 \\
EARNNEG & 13,938 & 1,845 & 0,387 & 7,555 & 0,000 \\
BV & 48615410781,521 & 6925610606,531 & 0,187 & 7,020 & 0,000 \\
OWN\% & 5,167 & 0,627 & 0,637 & 8,239 & 0,000 \\
Adjusted R & 0,999 & & & & \\
\hline \hline
\end{tabular}

The analysis supports the previous research finding that the market can reward government ownership in the banking and finance sector, because of potentially decreased risk of bankruptcy, access to subsidy, investors feel more secure about the assets of state controlled banks (beta-value of 0,187 ).

Transportation. Transportation also supports the assumption of the positive impact of government ownership, for the Russian transportation sector the impact is significant with the beta-value of 0,359 , an interesting fact seems to be that the size of earnings does not contribute in market value prediction (a negative beta-value), the only important effect is the absence of loss.

\section{Regression Results for Transportation}

Table 14.

\begin{tabular}{l|rr|r|r|r}
\hline & \multicolumn{2}{|c|}{ Unstandardized coefficients } & \multicolumn{3}{c}{ Standardized coefficients } \\
\cline { 2 - 6 } & \multicolumn{1}{|c}{$\mathrm{B}$} & \multicolumn{1}{c}{ Std. error } & \multicolumn{1}{c}{ Beta } & \multicolumn{1}{c}{$\mathrm{t}$} & $\mathrm{p}$-value \\
\hline EARN & $-24,949$ & 3,511 & $-1,270$ & $-7,105$ & 0,000 \\
EARNNEG & 24,809 & 3,876 & 1,190 & 6,401 & 0,000 \\
BV & 1,871 & 0,176 & 0,538 & 10,622 & 0,000 \\
OWN\% & 1630072864,343 & 219391392,912 & 0,359 & 7,430 & 0,000 \\
Adjusted R & & & & & \\
\hline \hline
\end{tabular}


The transportation sector may display a large impact of government ownership due to the fact that the sector naturally creates negative externalities, constantly produces insufficient socially desirable quantity of service, and thus has to be subsidized by the government. This results in a very low margin of profit for transportation sector in Russia.

Retail. The food and retail sector is also affected by government ownership and this effect is also positive (Table 15), which means that the market rewards state control, however the results are not conclusive due to low significance of some elements of the model. The association between state control and market value has a high beta $(0,29)$ at the significance level $<0,05$.

Regression Results for Retail

Table 15.

\begin{tabular}{|c|c|c|c|c|c|}
\hline & \multicolumn{2}{|c|}{ Unstandardized coefficients } & \multicolumn{3}{|c|}{ Standardized coefficients } \\
\hline & B & Std. error & Beta & $\mathrm{t}$ & p-value \\
\hline EARN & $-3,997$ & 2,007 & $-0,191$ & $-1,991$ & 0,094 \\
\hline OWN\% & 1859359914670,728 & 395513755665,476 & 0,290 & 4,701 & 0,003 \\
\hline EARNNEG & 19,009 & 4,272 & 0,745 & 4,450 & 0,004 \\
\hline BV & 0,679 & 0,475 & 0,193 & 1,429 & 0,203 \\
\hline Adjusted $\mathrm{R}^{2}$ & 0,992 & & & & \\
\hline
\end{tabular}

We can predict the intercept in food and retail with the probability of 0,99 which is also extremely high, using only the share of government ownership and positive financial results.

The more densely populated sector was the sector of energy, which displayed strong collinearity but proved to be untestable. However, if model restrictions are disregarded, then government ownership in the energy sector has no significant impact on market value.

\section{Conclusion}

Russia is a country with a strong centralized government and state controlling of up to $100 \%$ of equity in some firms, however investors do not seem to either penalize or praise such control at least not in the market in total. To see the actual market-relevance of the government ownership we have to include the factor of industry.

The industry effect proved to be significant. In general, the market seems to reward belonging to the service sector and penalize manufacturing. However, there are sectoral differences: government control is severely penalized in mining and metal sector, while in banking, transportation and retail it seems to be rewarded by the market.

We explain these differences by the dissimilar effects expected by investors in these sectors. In mining, investors obviously dread the «grabbing hand» effect, in transportation they hope for state subsidy, and in banking - decreased bankruptcy risk. Food and retail praise government ownership probably also due to risk factors, such as political risks.

Our results support the findings of Huang and Xiao (2012) and Truong et al., (2006) which claim that the relationship between government control and market value is higher for transition economies. We find that Russian investors do take into consideration the factor of govern- 
ment control when making investment decisions; however that consideration depends on the industry and for the whole market this assumption does not hold if the factor of industry is not taken into consideration. In the presence of industry factor government ownership does matter, but only if it is a concentrated value of more than $50 \%$ of equity. The further breakdown into industries sustained this result and showed that government ownership is more significant in service sectors.

Our results are in line with the efficient market hypothesis, which means that various factors affect the market value of the firms listed in Russian stock exchange, top ten firms by market value display a mean share of government control of $50 \%$. Our results partially contradict the Agency cost theory, the evidence is against agency costs where the concentration of ownership effect overpowers the agency cost effects (ultimate control effect, «grabbing hand» effects), only in the presence of industry factor; the effect is not proved in all other instances, hence partial contradiction, as no statistically significant positive association was found. Our results support Agency theory in the part of concentration of ownership hypothesis.

Practical recommendations based on the results of this study may be addressed both to firm managers and for shareholders. The findings should be used while developing a strategy of the equity management of a corporation, determining the direction of a capital management policy and developing the stages of its implementation. Firm managers in service sector planning financial and investment strategies for their enterprises under the assumption of EMH should take into account the positive effects of concentrated government ownership on market value, while managers in the manufacturing sector should beware of such engagements.

For the government as a shareholder, the management of state-owned shares now is extremely important - more substantial than management of state-owned enterprises, from the point of view of both the firm value characteristics and the development perspectives. Thus the consequences of increasing/decreasing share of government-owned equity should be taken into account.

Future research may include triangulating the findings by qualitative research through interviews with industry officials and large investors to explain the positive or negative impact of state control, as well as comparison of results on Russian markets with other transition economies. Another stream of future research may test the market for efficiency and correct the results of market value relevance studies based on the resulting efficiency form.

\section{References}

Alfaraih M., Alanezi F., Almujamed H. (2012) The Influence of Institutional and Government Ownership on Firm Performance: Evidence from Kuwait. International Business Research, 5, 10, pp. 192-200. Available at: https://doi.org/10.5539/ibr.v5n10p192.

Boubakri N., El Ghoul S., Guedhami O., Megginson W.L. (2018) The Market Value of Government Ownership. Journal of Corporate Finance, 50, 405, pp. 44-65. Available at: https://doi.org/10.1016/ j.jcorpfin.2017.12.026. 
Boycko M., Shleifer A., Vishny R. (1996) A Theory of Privatisation. Economic Journal, 106, iss. 435, pp. 309-319.

Brealey R.A., Myers S.C., Allen F. (2008) Principles of Corporate Finance. McGraw-Hill.

Brecht van D., Maga A., Luciani K. (2018) Exploring the Link between ESG Disclosure and Market Value of the Firm: Evidence from Thai Listed Companies. ASEAN Journal of Management \& Innovation. Working Paper (in press).

Carney R.W., Child T.B. (2013) Changes to the Ownership and Control of East Asian Corporations between 1996 and 2008: The Primacy of Politics. Journal of Financial Economics, 107, iss. 2, pp. 494-513.

Eckel C.C., Vermaelen T. (1986) Internal Regulation: The Effects of Government Ownership on the Value of the Firm (October 1, 1986). Journal of Law and Economics, 29, 2, p. 381. Available at: https://ssrn.com/abstract=1883677.

Fama E.F. (1970) Efficient Capital Markets: A Review of Theory and Empirical Work. Journal of Finance, 25, 2, pp. 383-428.

Fama E.F. (1991) Efficient Capital Markets: II. Journal of Finance, 46, 5, pp. 1575-617.

Fama E.F. (1998) Market Efficiency, Long-term Returns, and Behavioral Finance. Journal of Financial Economics, 49, pp. 283-306.

Fenton O'Creevy M., Nicholson N., Soane E., Willman P. (2005) Traders: Risks, Decisions, and Management in Financial Markets. Oxford: Oxford University Press.

Guedhami 0. (2012) Characteristics of Government Acquisitions over Time: International Evidence and Crisis Effect. Privatization Barometer Report, pp. 30-42.

Hassel L., Nilsson H., Nyquist S. (2005) The Value Relevance of Environmental Performance. European Accounting Review, 14, 1, pp. 41-61.

Hess K., Gunasekarage A., Hovey M. (2010) State-Dominant and Non-State-Dominant Ownership Ownership Concentration and Firm Performance: Evidence from China. International Journal of Managerial Finance, 6, 4, pp. 264-89.

Huang L., Xiao S. (2012) How Does Government Ownership Affect Firm Performance? A Simple Model of Privatization in Transition Economies. Economics Letters, 116, pp. 480-482.

Huang X., Kabir R., Zhang L. (2018) Government Ownership and the Capital Structure of Firms: Analysis of an Institutional Context from China. China Journal of Accounting Research, 11, 3, pp. 171-185. Available at: https://doi.org/10.1016/j.cjar.2018.07.001

Husain S., Hazoor T., Sabir M. (2014) Impact of Family Ownership on Market Value of a Firm: a Comparative Analysis of Family and Non-Family Companies Listed at Karachi Stock Exchange. Pakistan. International Journal of Management and Sustainbility, 3, 12, pp. 673-683.

Jensen M., Meckling W. (1976) Theory of the Firm: Managerial Behavior, Agency Costs and Ownership Structure. Journal of Financial Economics, 3, pp. 306-360.

Jiang B.B., Laurenceson J., Tang K.K. (2008) Share Reform and the Performance of China's Listed Companies. China Economic Review, 19, 3, pp. 489-501.

Kendall M. (1953) The Analysis of Economic Time Series - Part 1: Prices. Journal of the Royal Statistical Society, A, 116, pp. 11-25.

Khan M.I. (2012) Capital Structure, Equity Ownership and Firm Performance: Evidence from India. January 2012. Available at: https://doi.org/10.2139/ssrn.2016420

Liao J., Young M. (2012) The Impact of Residual Government Ownership in Privatized Firms: New Evidence from China. Emerging Markets Review, 13, pp. 338-351.

Loh L., Thomas T., Wang Y. (2017) Sustainability Reporting and Firm Value: Evidence from Singapore-Listed Companies. Sustainability, 9, 11, 2112, pp. 1-12.

Lourenço I., Branco M., Curto J., Eugénio T. (2012). How Does the Market Value Corporate Sustainability Performance? Journal of Business Ethics, 108, 4, pp. 417-428.

Modigliani F., Miller M.H. (1958) The Cost of Capital, Corporation Finance and the Theory of Investment. The American Economic Review, 48, 3, pp. 261-297. 
Modigliani F., Miller M.H. (1963) Corporate Income Taxes and the Cost of Capital: A Correction. The American Economic Review, 53, 3, pp. 433-443.

Morck R., Shleifer A., Vishny R.W. (1988) Management Ownership and Market Valuation: An Empirical Analysis. Journal of Financial Economics, 20, pp. 293-315.

Nash R. (2017) Contracting Issues at the Intersection of the Public and Private Sectors: New Data and New Insights. Journal of Corporate Finance, 42, pp. 357-366.

Ohlson J.A. (1995) Earnin gs, Book Values, and Dividends in Equity Valuation. Contemporary Accounting Research, 11, pp. 661-687.

Pound J. (1988) Proxy Contests and the Efficiency of Shareholder Oversight. Journal of Financial Economics, 20, pp. 237-265.

Razak N.H.A., Saidi N.A., Mahat F. (2013) The Relationship Between Government Ownership, Firm Performances and Leverage: an Analysis From Malaysian Listed Firms. Corporate Ownership and Control, 10, 4. Available at: https://doi.org/10.22495/cocv10i4art4.

Samuelson P. (1965) Proof that Properly Anticipated Prices Fluctuate Randomly. Industrial Management Review, 6, pp. 41-49.

Sappington D.E., Stiglitz J.E. (1987) Privatization, Information, and Incentives. Journal of Policy Analysis and Management, 6, 4, pp. 567-581.

Shleifer A., Vishny R. (1994) Politicans and Firms. Quarterly Journal of Economics, 109, pp. 995-1025.

Tahir S.H., Saleem M., Arshad H. (2015) Institutional Ownership and Corporate Value: Evidence From Karachi Stock Exchange (KSE) 30-Index Pakistan. Praktični Menadžment, Stručni Časopis Za Teoriju i Praksu Menadžmenta, 6, 1, pp. 41-49.

Tran N.M., Nonneman W., Jorissen A. (2014) Government Ownership and Firm Performance: The Case of Vietnam. International Journal of Economics and Financial Issues, 4(3), pp. 628-650.

Truong D.L., Lanjouw G., Lensink R. (2006) The Impact of Privatization on Firm Performance in a Transition Economy: The Case of Vietnam. Economics of Transition, 14, 2, pp. 349-389.

Wang K., Xiao X. (2009) Ultimate Government Control Structures and Firm Value: Evidence from Chinese Listed Companies. China Journal of Accounting Research, 2, 1, pp. 101-122. Available at: https://doi.org/10.1016/S1755-3091(13)60010-6.

Wei Z.B., Xie F.X., Zhang S.R. (2005) Ownership Structure and Firm Value in China's Privatized Firms: 1991-2001. Journal of Financial and Quantitative Analysis, 40, 1, pp. 87-108. 